JoFSA, Vol.1, No.1, April 2017, pp. 47-54

ISSN: 0000-0000

\title{
KETAHANAN VARIETAS PADI LOKAL MENTIK WANGI TERHADAP PENYAKIT BLAS
}

\author{
Yulianto ${ }^{1}$ \\ ${ }^{1}$ Balai Pengkajian Teknologi Pertanian Jawa Tengah \\ e-mail: yuliantobptpjateng@yahoo.com
}

\begin{abstract}
Mentik Wangi, one of the local rice varieties, is highly favored by rice farmers in Central Java. Marketers and consumers highly accept Mentik Wangi with its elliptical seeds because it has delicious taste and aroma. Besides having delicious taste, the variety is resistant to blast disease in various locations, whether planted in lowland or upland. In endemic blast disease areas, Mentik Wangi variety showed resistance to blast disease with low disease intensity, although the other varieties in these places showed quite high disease intensity. Rice blast disease is a disease that damages the rice not only on dry land, but also on rainfed and irrigation lands. At a high level of disease intensity, blast disease can cause yield losses of up to $100 \%$. Planting resistant rice variety to prevent damage due to blast disease is one of the methods to blast disease control which is effective, inexpensive, and safe for the environment. However, control of blast disease with one component such as planting resistant rice is estimated to be ineffective in the long term, because the pathogen causes the blast disease to be able to adapt to the rice variety to form a new race that is more virulent. A rice variety that is originally resistant will gradually become susceptible to the new pathogen race. When the rice varieties which are resistant to blast disease is controlled by a single gene (monogenic resistant), the resistance of these varieties within 2-4 planting seasons will be broken by a new pathogenic race. Mentik Wangi that shows resistance to blast disease in various rice planting regions is expected to have some of the resistance genes, so that it can be used as a durable resistant variety.
\end{abstract}

Keywords: Rice, Mentik Wangi, resistance, blast

\section{Pendahuluan}

Padi sebagai makanan pokok utama, perlu ditingkatkan dan dijaga stabilitas produksinya agar Bangsa Indonesia dapat memenuhi kebutuhan bahan pangan pokok sendiri. Varietas padi lokal, di antaranya Mentik Wangi, Pandan Wangi, Cianjur, Rojo Lele sangat populer di tingkat pedagang dan konsumen. Beras dari varietas-varietas lokal tersebut sangat digemari karena cita rasanya yang sesuai dengan selera para konsumen. Oleh karena permintaan pasar yang tinggi, para petani banyak yang selalu menanam varietas-varietas padi lokal tersebut.

Upaya khusus telah dilaksanakan Pemerintah untuk meningkatkan produksi bahan pangan pokok, dalam program UPSUS PAJALE (Upaya Khusus Padi Jagung Kedelai). Upaya terrsebut di beberapa sentra produksi padi telah membuahkan hasil yang menggembirakan karena mampu meningkatkan produktivitas secara signifikan. Namun di beberapa lokasi lain masih ada yang terkendala oleh adanya gangguan serangan hama dan penyakit tanaman. Salah satu penyakit tanaman padi yang saat ini sering merusak dan merugikan bagi petani adalah penyakit blas.

Penyakit blas pada tanaman padi dapat dijumpai pada berbagai stadia pertumbuhan dari pesemaian sampai menjelang panen (Yuliani dan Maryana, 2014; Sudir et al., 2014; BBPadi, 2015). Pada tanaman stadium vegetatif biasanya jamur penyebab penyakit (patogen) 
menginfeksi bagian daun, disebut blas daun (leaf blast). Pada stadium generatif selain menginfeksi daun juga menginfeksi leher malai, disebut blas leher (neck blast). Infeksi patogen blas juga dapat terjadi pada bagian buku tanaman padi yang menyebabkan batang patah dan kematian yang menyeluruh pada batang atas dari buku yang terinfeksi (Sudir et al., 2014; Taufik, 2011). Infeksi pada daun setelah fase anakan maksimum biasanya tidak menyebabkan kehilangan hasil yang terlalu besar, namun infeksi pada awal pertumbuhan sering menyebabkan puso terutama varietas yang rentan (Yulianto dan Subiharta, 2009).

Infeksi penyakit blas pada daun padi membentuk gejala bercak berbentuk belah ketupat. Pada kondisi lingkungan yang lembap dan hangat, gejala bercak daun akan meluas. Jika beberapa bercak daun tumbuh meluas dan menyatu maka daun-daun padi yang terinfeksi akan menjadi kering dan tanaman mati. Pada stadium generatif, terutama pada saat pengisian biji, sering ditemukan gejala penyakit blas leher malai. Malai padi yang terinfeksi parah oleh patogen blas menimbulkan gejala busuk kering pada leher malai. Gejala penyakit blas pada leher malai tersebut berwarna coklat kehitaman (gosong) seperti terkena letupan api (blast). Akibat serangan penyebab penyakit blas pada leher malai yang parah maka leher malai menjadi busuk kering dan mudah patah, aliran hasil fotosintesis ke bulir padi menjadi terhambat, sehingga apabila malai terinfeksi ketika masih stadium masak susu maka bulir padi yang dihasilkan banyak yang menjadi hampa. Perkembangan parah penyakit blas leher infeksinya dapat mencapai bagian gabah dan patogennya dapat terbawa gabah sebagai patogen tular benih (seed borne) (BBPadi, 2015).

Pada lingkungan yang kondusif, blas daun berkembang pesat dan kadang-kadang dapat menyebabkan kematian tanaman (Gambar 1). Penyakit blas leher dapat menurunkan hasil secara nyata karena menyebabkan leher malai mengalami busuk atau patah, sehingga proses pengisian malai terganggu dan bayak terbentuk bulir hampa (Gambar 2). Gangguan penyakit blas leher di daerah endemis sering menyebabkan tanaman padi menjadi puso (BBPadi, 2015; Yuliani dan Maryana, 2014; Nasution dan Usyati, 2015). Penyakit blas di Indonesia sudah menyebar di hampir semua sentra produksi padi (Sudir et al., 2014). Menurut Suganda et al. (2016), penyakit blas pada awalnya lebih dominan pada padi gogo, namun saat ini, patogen blas telah menyerang tanaman padi di dataran rendah beririgasi (lahan sawah) di seluruh Indonesia. Pada pertanaman padi di lahan sawah irigasi, kehilangan hasil akibat penyakit blas leher malai lebih tinggi daripada kehilangan hasil yang diakibatkan penyakit blas daun (Teng et al., 1991).

Patogen blas selain menyerang tanaman padi juga dapat menyerang serealia lain seperti gandum, sorgum, dan lebih dari 40 spesies graminae (Santoso dan Nasution, 2008). Gulma yang banyak terdapat di lahan sawah, yaitu Echinochloa colona dan Digitaria cilaris adalah inang P. oryzae yang berperan sebagai sumber spora pada periode bero. Miselia patogen tersebut dapat bertahan selama setahun pada jerami sisa-sisa panen (Teng et al., 1991). Selain gulma-gulma tersebut, sumber spora juga banyak yang berasal dari sisa-sisa jerami tanaman padi yang terinfeksi penyakit blas. Suwandi et al. (2016) menyatakan bahwa sisa-sisa jerami tanaman sakit di lapangan dapat menjadi sumber inokulum bagi tanaman musim berikutnya.

Setiap tanaman memiliki respon ketahanan yang berbeda-beda terhadap infeksi patogen. Perbedaan respon ketahanan mungkin disebabkan oleh perbedaan morfologi atau genetik tanaman atau mungkin adanya perbedaan kandungan bahan kimia atau metabolit sekunder yang dimiliki oleh masing-masing tanaman. Tanaman yang memiliki morfologi yang sulit dipenetrasi oleh patogen karena ketebalan dinding sel atau kemampuan membentuk struktur-struktur pertahanan seperti papilla, atau kalosa maka tanaman tersebut mampu melawan penetrasi patogen (Taufik, 2011). Secara genetik ketahanan varietas dapat dibagi menjadi 2 bagian, ketahan vertikal dan horizontal, dimana ketahanan vertikal adalah ketahanan varietas terhadap satu ras atau satu haplotipe suatu patogen. Sedangkan, ketahanan horizontal adalah ketahanan suatu varietas yang tersusun atas banyak gen, yaitu ketahanan yang tidak spesifik terhadap ras tertentu. Varietas tanaman yang memiliki 1 ketahanan ras kemungkinan mempunyai ketahanan vertikal. Sedangkan varietas yang memiliki ketahanan terhadap 2 ras blas atau lebih kemungkinan mempunyai ketahanan horizontal (Nasution dan Usyati, 2015).

JoFSA Vol. 1, No. 1, April $2017: 47-54$ 
Interaksi antara gen ketahanan dan patogen blas perlu diketahui untuk dijadikan dasar dalam perakitan varietas baru tahan blas, dan menentukan varietas tahan yang spesifik lokasi dengan komposisi patogen blas yang berkembang di lokasi tersebut. Guna menentukan dan memantau dinamika komposisi ras patogen blas yang berkembang disuatu wilayah, telah dikembangkan satu set perangkat uji berupa 7 varietas deferensial, yaitu Asahan, Cisokan, IR64, Krueng Aceh, Cisadane, Cisanggarung, dan Kencana Bali. Dengan menggunakan perangkat uji varietas diferensial tersebut, telah berhasil diidentifikasi jumlah ras patogen blas di Indonesia, yaitu sebanyak 64 ras (Sudir et al., 2014; Yuliani dan Maryana, 2014). Berdasarkan hasil uji adaptasi beberapa varietas padi di lahan tadah hujan di Pemalang yang merupakan daerah endemik penyakit blas, diperoleh varietas-varietas tahan blas, yaitu Mentik Wangi, Cibogo, dan Cigeulis (Yulianto dan Subiharta, 2009).

\section{Sifat-sifat unggul varietas Mentik Wangi}

Mentik Wangi adalah varietas padi unggul lokal yang banyak ditanam petani di Provinsi Jawa Tengah. Rasa nasi yang pulen disertai aroma yang harum membuat beras Mentik Wangi sangat digemari oleh konsumen. Padi Mentik Wangi memiliki ciri-ciri khas sebagai berikut: 1 . bentuk beras bulat lonjong, 2. gabah berwarna kuning kecoklatan, 3. aroma beras harum khas Mentik Wangi, 4. sesuai ditanam di lahan sawah, asalkan cukup akan pasokan airnya, 5. sesuai untuk dibudidayakan dalam sistem organik. Para petani suka menanam padi Mentik Wangi karena pemasarannya mudah dengan harga gabah kering panen (GKP) yang lebih tinggi daripada varietas padi unggul nasional. Selain memiliki keunggulan sifat-sifat fisik yang disukai oleh petani dan konsumen, varietas Mentik Wangi ternyata juga memiliki ketahanan terhadap penyakit blas.

\section{Jamur penyebab penyakit (patogen) blas}

Penyakit blas disebabkan oleh infeksi jamur yang terdiri atas dua jenis, yaitu yang mampu berkembang biak secara seksual dan yang aseksual (anamorf). Patogen blas yang mampu berkembang biak secara seksual diidentifikasi sebagai Magnaporthe oryzae Cav. yang semula diidentifikasi sebagai Magnaporthe gricea (T.T. Hebert) M.E. Barr. Sedangkan yang berkembang biak secara aseksual diidentifikasi sebagai Pyricularia oryzae Cav. yang semula diidentifikasi sebagai Pyricularia gricea (Cook) Sacc. Perkembang biakan jamur secara seksual hanya ditemukan di laboratorium, yaitu jika jamur penyebab penyakit blas tersebut (M. oryzae) ditumbuhkan pada media buatan. Pada media buatan tersebut M. oryzae membentuk ascospora. Sedangkan, jamur P. oryzae berkembang dan menyebar di alam dengan membentuk spora berupa konidia (TeBeest et al., 2007).

Patogen blas yang menginfeksi tanaman dapat memproduksi spora konidia secara optimal dari setiap bercak di daun maupun di leher malai dan setiap bercak mampu menghasilkan 2000 -6000 konidia per hari. Pelepasan konidia berlangsung jika kelembapan nisbi $>90 \%$. Produksi konidia tersebut dapat berlangsung selama $10-14$ hari. Konidia jamur berbentuk lonjong yang meruncing pada ujungnya. Konidia tersebut bening transparan, yang terdiri atas 3 sel. Miselium (benang-benang jamur) juga bening transparan dan bersekat. Konidia dilepaskan dari bercak di daun maupun di leher malai, pada malam hari. Jarak tempuh penyebaran konidia yang terbawa angin dapat mencapai $2 \mathrm{~km}(\mathrm{Ou}, 1985)$. Konidia yang jatuh pada bagian tanaman padi akan berkecambah jika kelembapan nisbi tinggi, terdapat embun atau air hujan. Periode basah tersebut minimal terjadi selama 5 jam. Sekitar 50\% konidia akan mampu melakukan penetrasi 6 -8 jam dan infeksi terjadi melalui stomata. Periode laten untuk memproduksi kembali konnidia terjadi sekitar 4 hari. Suhu optimum untuk perkecambahan konidium dan pembentukan apresorium adalah $25^{\circ}-30^{\circ} \mathrm{C}$. Suhu optimum untuk terjadinya infeksi patogen adalah sekitar $25^{\circ}-26^{\circ} \mathrm{C}$. Peranan embun/titik hujan sangat menentukan keberhasilan infeksi. Masa inkubasi antara 5 - 6 hari pada suhu $26^{\circ}-28^{\circ}$ C. Suhu optimum untuk infeksi sama dengan suhu optimum yang diperlukan untuk pertumbuhan miselia, sporulasi, dan perkecambahan spora (Santoso dan Nasution, 2008). 


\section{Pengendalian Penyakit Blas}

Pengendalian penyakit blas dapat dilakukan melalui berbagai teknik. Teknik pengendalian yang paling banyak diterapkan oleh petani adalah melalui aplikasi fungisida. Teknik pengendalian lainnya yang telah dilakukan adalah pemberian pupuk berimbang, yaitu tidak melakukan pemupukan nitrogen berlebihan dan memberikan tambahan pupuk kalium. Pengaturan jarak tanam yang tidak terlalu rapat untuk mengurangi kelembapan dan meningkatkan penetrasi cahaya matahari merupakan teknik pencegahan perkembangan penyakit blas. Teknik pengendalian yang aman, murah, dan cukup efektif adalah penanaman varietas tahan dan pergiliran varietas yang ditanam dalam suatu areal lahan persawahan. Setiap teknik pengendalian penyakit blas tersebut memiliki kelebihan dan kekurangannya. Seringkali pengendalian penyakit blas yang dilakukan hanya menggunakan satu cara, kurang berhasil secara memuaskan. Oleh karena itu, pengendalian penyakit blas perlu dilaksanakan melalui pengelolaan teknik-teknik pengendalian secara terpadu.

Mew et al. (1986) menyatakan bahwa intensitas penyakit blas yang terjadi di lahan sawah tadah hujan dapat berbeda-beda antar musim tanam dan antar daerah yang berbeda. Curah hujan yang kurang, sangat mendukung terjadinya perkembangan penyakit blas di lahan tadah hujan. Tanaman padi yang kekurangan air akan menjadi rentan terhadap penyakit blas. Pesemaian dan pengelolaan pertanaman dengan penggenangan air yang cukup, dapat membantu pengendalian penyakit blas. Kekurangan air diduga menyebabkan kadar silikon tanaman rendah. Kandungan silikon dalam jaringan tanaman menentukan ketebalan dan kekerasan dinding sel sehingga mempengaruhi terjadinya penetrasi patogen kedalam jaringan tanaman. Tanaman padi yang berkadar silikon rendah akan lebih rentan terhadap infeksi patogen.

Jamur penyebab penyakit blas (Pyricularia oryzae) memiliki keragaman genetik yang tinggi karena memiliki kemampuan perkawinan silang antar haploid hifa yang berlainan genetiknya dan tingkat mutasi yang tinggi sehingga memungkinkan terjadinya segregasi dan rekombinasi antar ras yang berbeda kemudian menghasilkan ras baru (Santoso et al., 2007). Berhubung dominasi ras-ras jamur P. oryzae mudah berubah untuk penyesuaian diri terhadap tekanan lingkungan, maka suatu teknik pengendalian yang dilakukan terus menerus, lambat laun menjadi tidak efektif. Hal ini menunjukkan bahwa jamur penyebab penyakit blas mudah membentuk ras baru dengan tingkat virulensi tinggi sehingga dengan cepat dapat mematahkan ketahanan varietas. Oleh karena itu, diperlukan varietas tahan yang memiliki gen ketahanan banyak (polygenic resistant), agar sifat ketahanannya bertahan lama (durable resistant). Varietas tahan ini berguna untuk mengatasi penyakit blas yang sebaran dan banyaknya ras berbeda-beda pada setiap lokasi (Sudir et al., 2014).

Penanaman suatu varietas tahan terhadap penyakit blas yang hanya memiliki satu gen tahan (monogenic resistant) seringkali tidak bertahan lama. Varietas tahan tersebut jika ditanam terus menerus, selama $2-4$ kali tanam, akan patah ketahanannya terhadap jamur penyebab penyakit blas (Santoso et al., 2007). Yulianto et al. (2014) melaporkan bahwa varietas Situ Bagendit di Klaten sangat rentan terhadap penyakit blas leher malai, namun pada musim tanam yang sama varietas Situ Bagendit yang ditanam di Pati memperlihatkan ketahanan terhadap penyakit blas leher malai. Hal tersebut diduga karena sebaran dan banyaknya serta dominasi ras yang muncul pada setiap lokasi berbeda-beda (Sudir et al., 2014). Dominasi ras patogen blas di suatu wilayah dengan wilayah lain yang berbeda, memungkinkan varietas padi di suatu wilayah tahan tetapi rentan di wilayah lain, karena ras-ras patogen tersebut memiliki virulensi yang berbeda berdasarkan tempat dan musim tanam (Yuliani dan Maryana, 2014).

\section{Tingkat ketahanan varietas Mentik Wangi di berbagai daerah terhadap blas}

Berdasarkan hasil survei penyebaran penyakit blas di Provinsi Jawa Tengah, ditemukan bahwa padi varietas lokal Mentik Wangi ternyata memiliki ketahanan terhadap penyakit blas yang lebih tinggi daripada varietas unggul nasional di lokasi-lokasi penghasil padi (Yulianto et al., 2014). Tingkat ketahanan varietas Mentik Wangi dibandingkan dengan varietas lainnya, dinyatakan dalam tingkat intensitas penyakit blas pada varietas-varietas tersebut. Makin rendah

JoFSA Vol. 1, No. 1, April $2017: 47-54$ 
intensitas penyakit blas pada suatu varietas padi, berarti makin tinggi tingkat ketahanan varietas padi tersebut terhadap penyakit blas. Pada berbagai daerah yang disurvei, intensitas penyakit blas pada Mentik Wangi sangat rendah dibandingkan varietas padi lainnya (Tabel 1).

Tabel 1. Tingkat intensitas penyakit blas di beberapa lokasi di Jawa Tengah

\begin{tabular}{ccc}
\hline Lokasi & Varietas padi & Rata-rata Intensitas penyakit \\
Kecamatan - Kabupaten $)$ & Mentik Wangi $(\%)$ \\
\hline Kaliangkrik - Magelang & Ciherang & 0 \\
& Mentik Wangi & 25 \\
Jenawi - Karanganyar & Mekongga & 5 \\
& IR64 & 25 \\
Tawangmangu - Karanganyar & Mentik Wangi & 10 \\
& IR64 & 4 \\
\hline
\end{tabular}

Sumber: Yulianto et al., 2014.

Berdasar data hasil survei penyebaran penyakit blas di beberapa daerah tersebut (Tabel 1), terdapat dugaan bahwa ada perbedaan dominasi ras-ras P. oryzae yang berkembang di lokasi yang berbeda. Varietas IR64 yang ditanam di Jenawi mengalami infeksi blas dengan intensitas penyakit $10 \%$, sedangkan yang ditanam di Tawangmangu mengalami infeksi blas dengan intensitas penyakit $48,5 \%$. Walaupun ras-ras jamur P. oryzae dominasinya berbeda di lokasi yang berbeda, intensitas penyakit blas pada varietas Mentik Wangi yang ditanam di lokasilokasi tersebut hanya mencapai 5\% dan 4\%. Tingkat ketahanan yang dimiliki varietas Mentik Wangi terhadap penyakit blas di berbagai daerah tersebut mengindikasikan bahwa varietas Mentik Wangi memiliki tipe ketahanan horizontal yang bersifat lebih stabil (durable) dari pada ketahanan vertikal. Ketahanan varietas Mentik Wangi yang bersifat durable tersebut sangat diperlukan sebagai tetua yang akan menjadi sumber gen ketahanan dalam melakukan persilangan guna menghasilkan varietas unggul tahan penyakit blas. Varietas baru tersebut akan sangat berguna dalam usaha pengendalian penyakit blas. Menurut Yuliani dan Maryana (2014) pengendalian penyakit blas dengan merakit varietas padi yang memiliki ketahanan durable dan bersifat poligenik merupakan salah satu cara untuk menghadapi patogen blas yang bersifat multiraces dan sangat dinamik. Prabawa, et al. (2015) menyatakan bahwa untuk mengatasi beragamnya ras dari jamur P. oryzae perlu dillakukan pemuliaan untuk mendapatkan genotip padi yang ketahanannya sulit dipatahkan. Varietas Mentik Wangi yang mempunyai keunggulan cita rasa dan aroma sesuai preferensi konsumen, diharapkan jika digunakan sebagai tetua dalam persilangan, akan menghasilkan varietas unggul baru tahan blas yang diterima oleh pengguna yaitu petani. Varietas Mentik Wangi yang telah lama ditanam di suatu daerah, ternyata tidak mengalami infeksi parah oleh P. oryzae. Diduga varietas Mentik Wangi memiliki gen-gen tahan terhadap jamur P. oryzae dalam jumlah banyak. Ketersediaan keragaman genetik merupakan salah satu faktor penting untuk menunjang program pemuliaan padi (Utami et al., 2010).

Varietas Mentik Wangi di Kecamatan Jenawi Kabupaten Karanganyar yang mengalami serangan patogen blas dengan intensitas penyakit 5\% menghasilkan panen gabah 6,984 t/ha. Sedangkan varietas Mekongga yang intensitas penyakit blasnya $25 \%$ menghasilkan panen gabah 6,8 t/ha. Informasi kelayakan usahatani padi varietas Mentik Wangi dibandingkan dengan varietas Mekongga dilakukan dengan menghitung B/C rasionya. Analisis ekonomi usahatani padi tersebut mengacu model Analisis Ekonomi Usahatani Padi Semi Organik dan Anorganik pada Petani Penggarap (Studi Kasus: Desa Ciburuy dan Desa Cisalada, Kecamatan Cigombong, Kabupaten Bogor) yang dikemukakan Sari, (2011). Berdasarkan analisis usahatani padi tersebut, varietas Mentik Wangi dalam usaha per hektar menelan biaya produksi Rp. 13.715.000,- dengan penerimaan petani Rp. 30.031.200,- mendapat keuntungan Rp. 16.316.200,- . Besar B/C rasio usahatani padi varietas Mentik Wangi 1,19 . Varietas Mekongga yang usahataninya menelan biaya produksi Rp. 13.623.000,- dengan penerimaan petani Rp. 
27.880.000,- mendapat keuntungan Rp. 14.257.000,- . Besar B/C rasio usahatani varietas Mekongga 1,05 (Tabel 2). Hal ini membuktikan bahwa penanaman varietas Mentik Wangi dalam kondisi terjadi epidemi penyakit blas, hasilnya lebih tinggi dan lebih menguntungkan petani daripada penanaman varietas Mekongga.

Tabel 2. Analisis Usahatani Padi Varietas Mentik Wangi dan Varietas Mekongga per hektar

\begin{tabular}{lrr}
\hline Kegiatan & Mentik Wangi (Rp.) & Ciherang $($ Rp. $)$ \\
\hline Pembuatan pesemaian & 900.000 & 900.000 \\
Harga benih $30 \mathrm{~kg} / \mathrm{ha}$ & 375.000 & 360.000 \\
Pengolahan tanah & 900.000 & 900.000 \\
Pembuatan pematang & 750.000 & 750.000 \\
Tanam & 1.200 .000 & 1.200 .000 \\
Pengendalian gulma & 1.480 .000 & 1.480 .000 \\
Pemupukan I & 280.000 & 280.000 \\
Pemupukan II & 280.000 & 280.000 \\
Harga pupuk & 1.090 .000 & 1.090 .000 \\
Pengendalian hama & 350.000 & 350.000 \\
Pestisida & 1.100 .000 & 1.100 .000 \\
Iuran irigasi & 900.000 & 900.000 \\
Pemanenan & 4.110 .000 & 4.033 .000 \\
Biaya produksi & $\mathbf{1 3 . 7 1 5 . 0 0 0}$ & $\mathbf{1 3 . 6 2 3 . 0 0 0}$ \\
Hasil panen $(\mathrm{kg})$ & 6.984 & 6.800 \\
Harga gabah (GKP)/kg & 4.300 & 4.100 \\
Pendapatan & & $\mathbf{2 7 . 8 8 0 . 0 0 0}$ \\
& & \\
Keuntungan & $\mathbf{3 0 . 0 3 1 . 2 0 0}$ & $\mathbf{1 4 . 2 5 7 . 0 0 0}$ \\
B/C ratio & & $\mathbf{1 , 0 5}$ \\
\hline
\end{tabular}

\section{Kesimpulan dan Saran}

\section{Kesimpulan}

Varietas Mentik Wangi yang tahan terhadap penyakit blas di berbagai daerah penghasil padi, diduga memiliki beberapa gen ketahanan atau ketahanan horizontal, sehingga tidak mudah patah ketahanannya (durable resistant). Varietas ini layak digunakan sebagai sumber gen dalam persilangan untuk membentuk varietas tahan penyakit blas. Dalam kondisi terjadi epidemi penyakit blas disuatu lokasi, penanaman varietas Mentik Wangi lebih menguntungkan daripada varietas Mekongga.

Pengendalian penyakit blas menggunakan varietas tahan, perlu didampingi teknik-teknik pengendalian lainnya seperti: pengaturan jarak tanam , pemenuhan kebutuhan air irigasi, pemupukan berimbang tanpa kelebihan nitrogen, sanitasi inang alternatif jamur P. oryzae, pergiliran varietas untuk mencegah pembentukan ras patogen baru yang virulen, dan penggunaan fungisida yang efektif.

Saran/rekomendasi

Para pemulia tanaman padi disarankan untuk menggunakan varietas Mentik Wangi sebagai tetua dalam persilangan untuk membentuk varietas tahan terhadap penyakit blas yang durable. Kepada para petani disarankan untuk melakukan pergiliran varietas padi tahan blas yang ditanam guna mencegah terjadi mutasi ras patogen blas yang berkembang di lahan pertanaman yang mampu merusak pertanaman padi.

\section{Saran}

Para pemulia tanaman padi disarankan untuk menggunakan varietas Mentik Wangi sebagai tetua dalam persilangan untuk membentuk varietas tahan terhadap penyakit blas yang durable. Kepada para petani disarankan untuk melakukan pergiliran varietas padi tahan blas 
yang ditanam guna mencegah terjadi mutasi ras patogen blas yang berkembang di lahan pertanaman yang mampu merusak pertanaman padi.

\section{Daftar Pustaka}

BBPadi. 2015. Penyakit Blas Pada Tanaman Padi dan Cara Pengendaliannya. http://bbpadi.litbang.pertanian.go.id/index.php/berita/info-teknologi/content/240penyakit-blas-pada-tanaman-padi-dan-cara-pengendaliannya. Diunduh: 1 April 2017.

Mew, T.W., Shahjahan A.K.M., Mariappan V. 1986. Diseases and disease management of rainfed lowland rice. Pages 339-348 in Progress in rainfed lowland rice. International Rice Research Institute, P.O. Box 933, Manila, Philippines.

Nasution A. dan N. Usyati. 2015. Observasi ketahanan varietas padi lokal terhadap penyakit blas (Pyricularia grisea) di rumah kaca. Prosiding Seminar Nasional Masyarakat BIODIV Indonesia. ISSN 2407-8050. 1 (1): 19 - 22.

Ou, S.H. 1985. Rice blast disease. (2nd ed). Commonwealth Mycological Institute Kew, Surrey. England. $380 \mathrm{p}$.

Prabawa P.S., I. Yulianah, dan N. Basuki. 2015. Uji Ketahanan 10 Genotip Padi Merah (Oryza sativa L.) Terhadap Penyakit Blas Daun (Pyricularia oryzae Cav.) Ras 173. Jurnal Produksi Tanaman. 3 (6): 496 - 502.

Santoso, A. Nasution, D.W. Utami, I. Hanarida, A.D. Ambarwati, S. Moeljoprawiro, dan D. Tharreau. 2007. Variasi Genetik dan Spektrum Virulensi Patogen Blas pada Padi Asal Jawa Barat dan Sumatera. Penelitian Pertanian Tanaman Pangan. 26 (3): 151 - 155.

Santoso dan A. Nasution. 2008. Pengendalian penyakit blas dan penyakit cendawan lainnya. Buku Padi 2. Hlm. 531-563. Dalam Darajat A.A., A. Setyono, A.K. Makarim, dan A. Hasanuddin (Ed.). Padi Inovasi Teknologi. Balai Besar Penelitian Tanaman Padi. Sukamandi. Badan Penelitian dan Pengembangan Pertanian.

Sudir, A. Nasution, Santoso, dan B. Nuryanto. 2014. Penyakit Blas Pyricularia grisea pada Tanaman Padi dan Strategi Pengendaliannya. IPTEK Tanaman Pangan. 9 (2): 85 - 96.

Suganda T, E. Yulia, F. Widiantini, dan Hersanti. 2016. Intensitas Penyakit Blas (Pyricularia oryzae Cav.) pada Padi Varietas Ciherang di Lokasi Endemik dan Pengaruhnya Terhadap Kehilangan Hasil. Jurnal Agrikultura. ISSN 0853-2885. 27 (3): 154 - 159.

Suwandi, H. Hamidson, dan A. Muslim. 2016. Penekanan Penyakit Blas Leher Malai Padi Menggunakan Ekstrak Kompos Jerami Padi. Jurnal Fitopatologi Indonesia. ISSN: 02157950. 12 (3): $104-108$.

Taufik M. 2011. Evaluasi Ketahanan Padi Gogo Lokal Terhadap Penyakit Blas (Pyricularia oryzae) di Lapang. AGRIPLUS ISSN 0854-0128. 21 (1): 68 - 74.

TeBeest D.O., Guerber C., and Ditmore M. 2007. Rice Blast. The Plant Health Instructor. DOI. 10.1094/PH 11-2007-0313-07 APSnet. Cited on 27 August 2016 from: http://apsnet.org/edcenter/intropp/lessons/fungi/ascomycetes/pages/riceblast.aspx.

Teng P.S., Klein-Gebbinck H.W., and Pinnschmidt H. 1991. An Analysis of the Blast Pathosystem to Guide Modeling and Forcasting. pp. 1-30. Los Banos, Philippines. International Rice Research Institute. 
Utami D.W., A.D. Ambarwati, A. Apriana, A. Sisharmini, I. Hanarida, dan S. Moeljoprawiro. 2010. Keragaan Sifat Tahan Penyakit Blas dan Agronomi Populasi Silang Balik dan Haploid Ganda Turunan IR64 dan Oryza rufipogon. Buletin Plasma Nutfah. 16 (2): 90 95.

Yuliani D. dan Y.E. Maryana. 2014. Integrasi Teknologi Pengendalian Penyakit Blas pada Tanaman Padi di Lahan Sub-Optimal. Prosiding Seminar Nasional Lahan Sub Optimal. Palembang 22-27 September 2014. ISBN 979-587-529-9. p. 835 - 845.

Yulianto dan Subiharta. 2009. Ketahanan padi varietas unggul baru terhadap penyakit blas(Magnaporthe gricea (T.T. Hebert) M.E. Barr) di lahan sawah tadah hujan Kabupaten Pemalang. Prosiding Seminar Ilmiah Nasional. BBP2TP dan UPN.

Yulianto, Sutoyo, dan B. Prayudi. 2014. Penyebaran penyakit blas pada tanaman padi di dataran rendah dan dataran tinggi Jawa Tengah. Seminar Hasil-Hasil Penelitian Pengkajian DIPA-APBN 2013 BPTP Jawa Tengah. Ungaran. 26p. 